\title{
Contributions to the Knowledge of the Plagiochilaceae of Southeastern Asia VIII. The Genus Plagiochilidium Herz.
}

\author{
by Hiroshi InouE*
}

Received June 1, 1966

The genus Plagiochilidium, described by Herzog ${ }^{1)}$ from Borneo, includes a single species, P. bornensis. This monotypic genus has received little attention since Herzog, although Schuster (pp. 18-19) ${ }^{2}$ discussed it briefly. Herzog ${ }^{1)}$ originally considered Plagiochilidium to be very close to Jamesoniella because of its habit, leaf, absence of underleaf, distinct differentiation of bracts and the structure of the female inflorescence. He included Plagiochilidium in the Lophoziaceae together with Plagiochila. However, since the work of Buch et al. ${ }^{3}$, it has been placed in the Plagiochilaceae. Schuster" agrees with this and remarked that "the assumption of an affinity to Jamesoniella, expressed by Horzog in $\cdots$, appears far-fetched to me." Schuster's conclusion was apparently based only on the Herzog's original description and drawings. I was able to study the type specimen of Plagiochilidium in $\mathrm{hb} \mathrm{JE}$ and the present paper is the result of this study.

\section{Observations}

Stem anatomy The stem is prostrate and somewhat dorsiventrally flattend. In cross section, it is 11-14 cells thick and 12-16 cells wide. The cortical cells are not well developed and only at the lower portion of the stem is a single layer of cortical cells observed. The cortical cells are little smaller than the medullary cells and have pale brown walls. The cell walls in the cortical and medullary layers are more or less uniformly thickened. No mycorrhizal cells were seen.

Branching The plants are poorly branched but appear to be of the postical intercalary type, arising from near the postical end of leaf-margins. The subfloral innovations are also postical intercalary. There are no other branching types.

Leaves and leaf-cells The leaves are nearly horizontally spreading and oblong in outline. The insertion line is oblique. Sometimes the dorsal margin of leaf is slightly revolute and the distal half is reflexed. The shape of apices varies but they are usually nearly truncate. However, especially near the female and male inflorescence, the apices are retuse or sometimes asymmetrically bilobed up to $1 / 4$ of the leaf-length. The leaf cells are $20-30 \times 20-27 \mu$ at the apex and along margin, $30-50 \times 30-35 \mu$ at the middle, and $28-35 \times 45-60 \mu$ at the base. The cell walls are usually slightly to moderately thickened only along the leaf-margin and thin throughout the middle to base. The outermost walls of cells along the margins are usually extremely thickened. The trigones are distinct and triangular, never nodulose. In a cross section of the leaf, the tangential walls of cells at the base are extremely thickened whereas the longitudinal walls are thin, but in the middle to apical portion of leaf, they are nuiformly thin. The cuticle is smooth but along the leaf-margin sometimes striolate

\footnotetext{
* Division of Cryptogams, National Science Museum, Tokyo.
} 


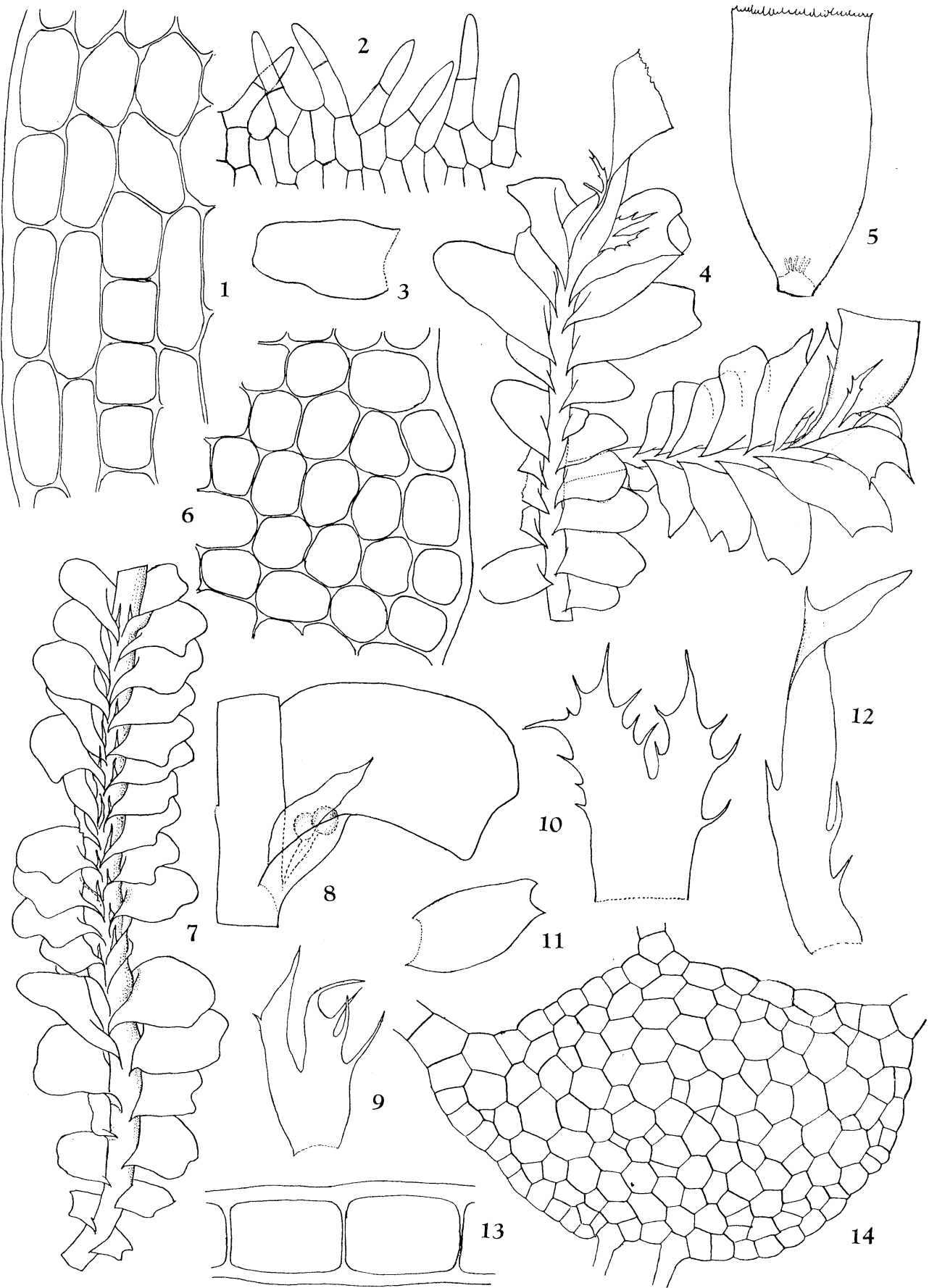

Figs. 1-14. Plagiochildium borensis Herz. 1, Cells from postical base of leaf, $\times 300$; 2, Part of perianth mouth, $\times 160 ; 3,11$, Leaves, $\times 10 ; 4$, Part of plant with female inflorescences, dorsal view, $\times 10 ; 5$, Perianth, $\times 16 ; 6$, Cells from leaf margin, $\times 300 ; 7$, Part of plant with male inflorescence, dorsal view, $\times 10 ; 8$, Male bract and antheridia, $\times 40 ; 9,10$, Bracts, $\times 16 ; 12$, Bracteoles, $\times 40 ; 13$, Part of cross section of leaf (at basal portion), $\times 300 ; 14$, Cross section of stem, $\times 160$. All figs. based on the type. 
verrucose.

Rhizoids and underleaves The underleaves are totally absent, even near inflorescence. The rhizoids are restricted to the postical leaf-bases. Some rhizoids rarely developed from postical surface of lower portion of stem.

Male inflorescence The plants seem to be dioecious, although male and female plants are intermixed. I was not able to find any monoecious plants. The male inflorescence are usually intermediate on the stem. The bracts are closely imbricate with the distal half nearly horizontally spreading. The bract insertion line is approximately J-shaped. The dorsal margin in somewhat saccate and inflated, and the apex is usually retuse or emarginate. There is always a large, triangular paraphyllium at the dorsal end of bract-margins. The paraphyllium is usually connate with the inner side or dorsal margin of the bract in various degrees. No paraphises are observed. These are 1-2 antheridia with stalk 2-cells wide and 8-15 cells long. Bracteoles are totally absent.

Female inflorescence The female inflorescence are terminal on the main stem of branches, rarely with an innovation. The bracts are strongly differentiated from the leaves and are approximately $1.5 \mathrm{~mm}$ long and $1 \mathrm{~mm}$ wide and bilobed to $1 / 2$ their length. The margins are irregularly dentate or dentate-ciliate. The bracteoles are linear-lanceolate and about $1 \mathrm{~mm}$ long and $0.18 \mathrm{~mm}$ wide with dentate margins. The bract-base and bracteoles are completely free. The perianth is laterally compressed with truncate and minutely dentate-ciliate margins. There are relatively few archegonia, usually 9-13. No sporophytes are seen.

\section{Relationship of the Genus}

Considering perianth form alone, the genus Plagiochilidium should probably be assigned to the Plagiochilaceae, but the structure of the male and female inflorecences are very unusual within the family.

In the Plagiochilaceae, Plagiochilidium has close affinity to Xenochila, as previously discussed by Inoue ${ }^{4)}$. Both genera have (1) simple stem structure, (2) localized rhizoids, (3) complete absence of underleaves, and (4) broadly inserted leaves. However, the branchings in Xenochila are never postical intercalary but terminal Frullania-type, and plants of Xenochila have numerous, green and multicellular gemmae. In Plagiochilidium no asexual reproductive structures have been observed. The female Inflorescence of Xenochila tends to be more Plagiochiloid and the bracts show essentially no differentiation from leaves lacking bracteoles. These features (except gemmae) clearly reflect the strong Plagiochiloid affinities of Xenochila.

In Plagiochilidium, on the other hand, the female and male inflorescences retain a closer affinity to Jamesoniella in the subf. Jamesonielloideae of Lophoziaceae ${ }^{5}$. Syzygiella and Jamesoniella resemble Plagiochilidium in many ways. However, Plagiochilidium should not be included in this subfamily only on the basis of Plagiochiloid perianth form and total absence of reddish pigmentation. Carl ${ }^{6)}$, in discussing Chiastocaulon, considered the perianth form of Plagiochilidum to be "Konvergenzbildung". I am unable to agree with Carl but feel that Plagiochilidium has a true Plagiochiloid perianth. Schuster ${ }^{2)}$ considered Plagiochilidium to be closer to Chiastocaulon and claimed any affinity to Jamesoniella to be "far-fetched". Postical intercalary branching and localized rhizoids are common features of the Jamesoniella-Syzygiella -Plagiochilidium-Plagiochilion-Chiastocaulon complex. The sequence from Jamesoni- 
ella to Chiastocaulon show an evolutionary trend. Xenochila seems to be drived from Plagiochilidium and retains certain primitive Lophozioid features. Thus, Plagiochilidium is transitional between the Plagiochilaceae and Lophoziaceae.

The genera closely related to Plagiochilidium (Jamesoniella-Chiastocaulon complex) can be distinguished by the following key.

A. Perianth distinctly laterally compressed, never plicate at the upper half

B. Female bracteoles and paraphyllium on the axis of male inflorescences totally absent

C. Multicellular, green gemmae frequent; stem without any differentiation

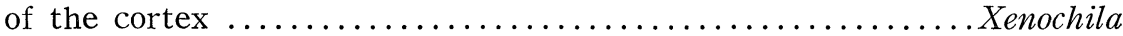

CC. Gemmae totally absent; stem usually with distinct differentiation of the cortex

D. Leaves distinctly opposite and connate, at least, at the postical ends; terminal Frullania-type branching absent............Plagiochilion

DD. Leaves alternate, never connate; Frullania-type terminal branching

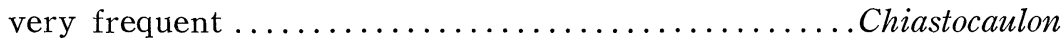

BB. Female bracteoles present; a large paraphyllium present at that end of male bract-margins Plagiochilidium

AA. Perianth cylindrical, plicate at the upper half, never laterally compressed

E. Leaves opposite and connate, at least, at the postical end ...... Syzygiella

EE. Leaves alternate, never connate .....................Jamesoniella

I am very much indebted to Dr. R. Grolle of the Institut für spezielle Botanik for his kindness in sending me the type specimen of Plagiochilidium bornensis. Acknowledgement is made of the partial financial support of this investigation through a grant from Japan Society for the Promotion of Science as a part of the Japan-U.S. Cooperative Science Program.

\section{Summary}

A morphological survey of the genus Plagiochilidium Herz. based on the type specimen in $\mathrm{hb} \mathrm{JE}$ is given. This genus is best included in the Plagiochilaceae and it is transitional between the Plagiochilaceae and Lophoziaceae with close affinities with Xenochila and Jamesoniella.

\section{Literature}

1) Herzog, T., Mitt. Inst. Allg. Bot. Hamburg 7: 182 (1931). 2) Schuster, R. M., Amer. Midl. Nat. 62: 1 (1959). 3) Buch, H., Evans, A. W., and Verdoorn, F., Ann. Bryol. 10: 3 (1937). 4) Inoue, H., Bull. Nat. Sci. Mus. Tokyo 6: 372 (1963). 5) Inoue, H., Journ. Hattori Bot. Lab. 29 (1966), in press. 6) Carl, H., Flora 126: 47 (1931).

\section{Additional Note}

Plagiochilidium bornensis Herz. was originally compared with Plagiochila linguifolia De Not. I was able to examine the type specimen of Plagiochila linguifolia in hb FI. The type specimen consists of only 4, very small, sterile fragments. The plants have a few postical intercalary branches, the rhizoids have strong tendency to be restricted to the leaf-bases, and the leaves are more or less laterally compressed with some 
reddish pigmentation at the margins. There are no underleaves. As noted by Herzog $^{1)}$, this species is indeed very similar to Plagiochilidium bornensis in vegetative characters. However, the laterally compressed leaves with pigmentation relate Plagiochila linguifolia more strongly to Jamesoniella. Among the tropical Asian species of Jamesoniella, this is closest to J. ovifolia but differs from it in the oblongligulate leaves.

Jamesoniella linguifolia (DeNot.) Inoue, comb. nov. = Plagiochila linguifolia De Not., Estr. Real. Acad. Sci. Trino, ser. 2, 28: 277. 1874. Type: Borneo, Sarawak, "fragmentula ad Gottscheam", leg. Beccari no. 51 in hb FI.

\section{摘 要}

井上 浩：アジア産ハネゴケ科への寄与 VIII. Plagiochilidium 属について

Plagiochilidium 属は Herzog によって Borneo から記載されて以来再度の報告を見ないし，この属に 関する詳細な研究もない. 今回, P. bornensis の基準標本を調べた結果, 本属は Plagiochilaceae の Xenochila 属㧍よび Lophoziaceae の Jamesoniella 属に近縁のもので, 花被の形態から明らかに Plagiochilaceae に含まれるが，雌苞葉，雄苞葉などの性質から考えて，Plagiochilaceae と Lophoziaceae の中 間に位置すると考学られる.Xenochila 属は明らかに Plagiochilidium に由来した属で, 無性芽や茎の構 造などに Lophoziaceae の性質が見られる。

[付] Plagiochilidium bornensis に近いとされた Plagiochila linguifolia は Jamesoniella 属のもの であるので, 学名の変更を要する. (国立科学博物館植物学部第二研究室) 